PNL-SA- -21320

DE93 004556

GRIDDED STATE MAPS OF WIND

ELECTRIC POTENTIAL

M. N. Schwartz

D. L. Elliott

G. L. Gower

October 1992

Presented at the

Windpower ' 92 Conference

October 19-23, 1992

Seattle, Washington

Prepared for

the U.S. Department of Energy under Contract DE-ACO6-76RLO 1830

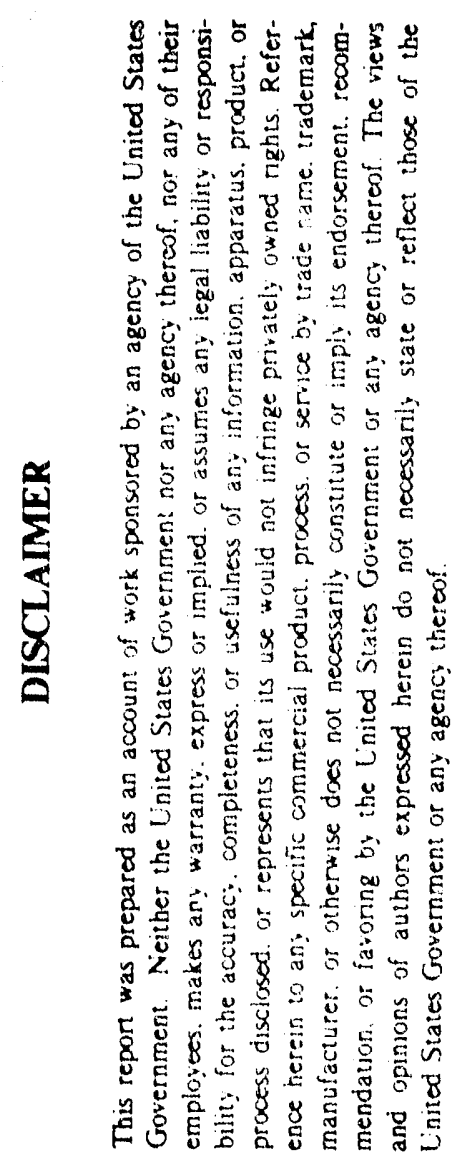

Pacific Northwest Laboratory

Richland, Washington 99352

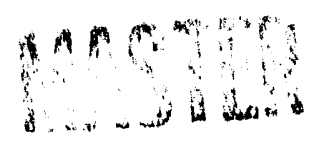




\title{
GRIDDED STATE MAPS OF WIND ELECTRIC POTENTIAL
}

\author{
M. N. Schwartz, D. L. Elliott, and G. L. Gower \\ Pacific Northwest Laboratory \\ Richland, Washington
}

\begin{abstract}
Estimates of wind electric potential and available windy land area in the contiguous United States, calculated in 1991, have been revised by incorporating actual data on the distribution of environmental exclusion areas where wind energy development would be prohibited or severely restricted. The new gridded data base with actual environmental exclusion areas, in combination with a "moderate" land-use scenario, is the basis for developing the first gridded maps of available windy land and wind electric potential. Gridded maps for the 48 contiguous states show the estimated windy land area and electric potential for each grid cell $\left(1 / 4^{\circ}\right.$ latitude by $1 / 3^{\circ}$ longitude). These new maps show the distribution of the estimated wind eiectric potential and available windy land within an individual state, unlike previous national maps that only show estimates of the total wind electric potential for the state as a whole.
\end{abstract}

While changes for some individual states are fairly large (in percentage), on a national basis, the estimated windy land area and wind electric potential are only about $1 \%$ to $2 \%$ higher than estimated in 1991.

\section{INTRODUCTION}

A 1987 wind energy resource atlas of the United States (1) showed that areas potentially suitable for wind energy applications were dispersed throughout much of the contiguous United States. A later study (2) quantified the land area available for wind energy development under various land-restriction scenarios for several levels of wind energy resource, both for the contiguous United States as a whole and for each of the 48 contiguous states. The two prime considerations in developing the land-restriction scenarios were environmental exclusion areas (including parks, monuments, wilderness areas, wildlife refuges, and other protected areas, where wind energy development would be prohibited or severely restricted) and land-use restrictions for various types of land (e.g., forest, agriculture, range, and urban lands). The distribution of environmental exclusion areas in the 1991 stı'dy was approximated, using existing data on land surface features (mountains, seashore etc.), because it was observed that the distribution of environmentally sensitive areas was correlated to certain land forms. These estimates have now been revised by incorporating actual data on the distribution of environmental exclusion areas. These areas are defined as national or state parks, monuments, forests, grasslands, seashores, recreation areas, wilderness areas, and wildlife refuges.

The new gridded data base of "actual" environmental exclusion areas, in combination with the existing gridded data bases of land-use types, land surface forms, and coastal and international border areas, as well as the restrictions imposed by the "moderate" land-use scenario in the 1991 report, provided the basis for developing updated gridded state maps of available windy lands and resultant wind electric potential. These new maps for the 48 contiguous states show the distribution of wind electric potential and available windy land on a finer scale than previous maps. Electric energy production potential, in megawatts of average power output, and available windy land, in square kilometers, are calculated for each grid cell of $1 / 4^{\circ}$ latitude by $1 / 3^{\circ}$ longitude throughout the contiguous United States. 


\section{ENVIRONMENTAL AND LAND-USE EXCLUSIONS}

In 1991, the percentage of land area excluded for environmental reasons was roughly estimated from a comparison of maps of federally administered environmental areas with maps of land-suriace form (2). The exclusions started at a minimum of $10 \%$ for land-surface forms that contained only a small percentage of environmentally designated lands. Other land-surface form exclusions were at least $50 \%$ for coastal areas and $90 \%$ for rugged mountainous terrain.

For this paper, we revised the data base of the percentage of land area in each grid cell excluded from wind energy development due to environmental considerations, to account for the actual distribution of both federally and state-administered environmentally designated land. Envirnnmental exclusion areas were defined as those lands, such as parks, monuments, wilderness areas, wildlife refuges, and other areas, where development is prohibited or severely restricted.

The distribution of federally administered environmental areas was for the most part estimated from a national map prepared by the U.S. Forest Service in 1979. This map featured all the types of federally administered land except for land in the National Wild and Scenic Rivers System. Land areas included in the National Wild and Scenic Rivers System, plus federal lands added to the system after 1979, were obtained from more recent detailed maps of the individual states. Environmental exclusion areas administered by states were also obtained from these state maps. State parks and forests accounted for most of the state lands excluded for environmental reasons. A few states had large natural and/or wildlife areas, and these lands were also excluded.

A map of the environmental exclusion land areas, including federal and state lands, is presented in Figure 1. The shading displays the percentage of each grid cell excluded for environmental reasons. The $90 \%$ and greater exclusion areas are concentrated in three main areas. The majority of these high-exclusion grid cells are in the

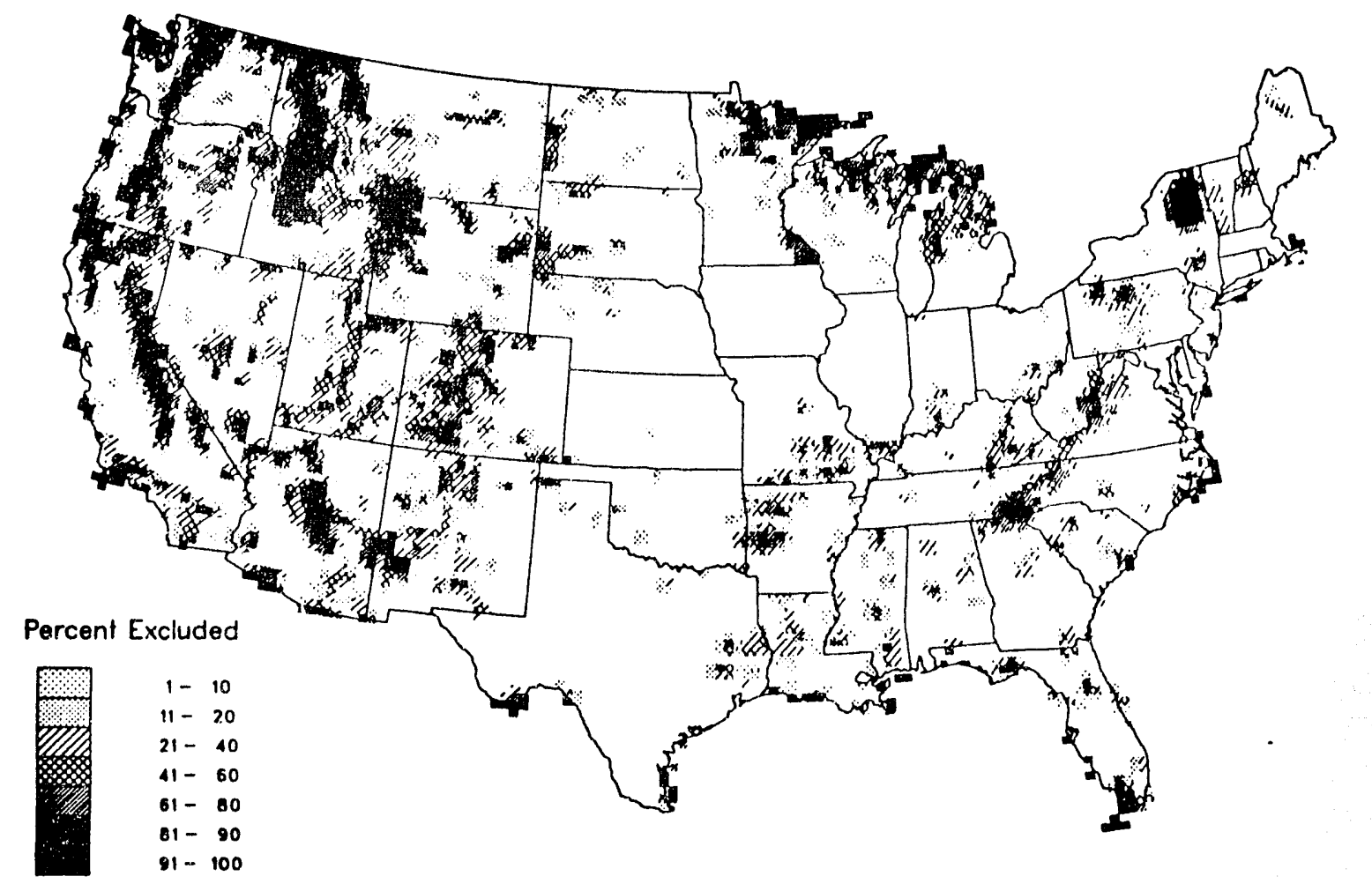

FIG. 1. PERCENTAGE OF EACH GRID CELL EXCLUDED DUE TO ENVIRONMENTAL CONSIDERATIONS 
mountainous west, in the Rocky Mountains and the Sierra Nevada and along the Cascade Range. The secondary areas of high environmental exclusions are along the Atlantic Oce 1, Gulf of Mexico, and Pacific Ocean coastlines. The third area with $90 \%$ or greater exclusions is the upper Great Lakes from Minnesota to Michigan. Other notable areas with high exclusions are the Appalachian and Ozark Mountains in the eastern United States and the Adirondack State Park in New York. In contrast to the high-exclusion areas, large parts of the midwest from Ohio west to Nebraska, north to North Dakota and South Dakota, and south to Texas have few environmental exclusion areas.

The land-use scenario used to update the windy land maps is a "moderate" land-use scenario (2). The land-use types considered are forest, agriculture, range, mixed agriculture/range, barren, wetland, and urban. The percentages of land excluded per land-use type are 10\% for range and barren lands, $20 \%$ for mixed agricultural/range land, $30 \%$ for agricultural land, $50 \%$ for forested land, and $100 \%$ for urban land and wetland. All urban land and wetland areas are excluded because no wind energy development is likely in those areas. Range and barren land has an exclusion of $10 \%$ to account for land that may be occupied by roads and structures. A $30 \%$ exclusion for agricultural lands was determined to be realistic after considering the physical and financial factors of wind energy development. For forest lands, $50 \%$ of the land area was excluded. The most important forested areas are mountainous regions, where the highest wind resources are found on the inountain crests. Windy ridge crests are often devoid of trees or have relatively small and scattered trees. It may not be necessary to remove any of the small trees (no taller than $10 \mathrm{~m}$ ) if tall $($ e.g., $50 \mathrm{~m}$ ) towers are used. Thus, it appears reasonable to include much of the land area associated with windy ridge crests in forested lands that could be utilized for wind energy development. In forests located in windy non-mountainous terrain, the wind resource is largely dependent on the height and density of trees near the exposed site. Data on height and density of the trees were not available in the data base. After considering all types of terrain, and the variability of the height and density of trees of different regions and different elevations, an exclusion of $50 \%$ was chosen for forested areas in this land-use scenario.

\section{WIND ELECTRIC POTENTIAL AND WINDY LAND ESTIMATES}

Revised maps of wind electric potential and available windy lands were produced based on the wind resource data base used in the 1987 atlas (1) and the revised environmental exclusion data base. Before calculating the wind energy potential from the available windy lands, the land exclusion estimates were made as conservative as possible to account for other lands that might be excluded from development. These include transportation right-of-ways, locally administered park land, privately administered areas, and proposed environmental lands. Consequently, a minimum exclusion of $10 \%$ was assigned to each grid cell that had either none or a small fraction of its land specifically designated as environmentally excluded. This report presents maps of windy land areas for two power classes (see Table 1). These are windy lands of class 4 and above for an assumed wird turbine hub height of $30 \mathrm{~m}$, and windy lands of class 3 and above for a hub height of $50 \mathrm{~m}$. Advanced turbine technology will allow areas with these wind power class resources to be developed. The formulas for calculating the windy land area in a grid cell and the power produced per grid cell are unchanged from the 1991 report (see Table 2).

The map of windy lands, in square kilometers, for power class 4 and above is presented in Figure 2a. The grid cells with the most windy land area are located from northern Texas through southern Kansas and in eastern Colorado, southwestern Nebraska, and southeastern Wyoming. However, since the size of a grid cell decreases as one moves north, this map of absolute value of available windy lands may overemphasize the area in the southern part of the coritiguous states as opposed to areas near the Canadian border. Therefore, the map of available windy lands expressed as a percentage of each grid cell (Figure 2b) emphasizes the excellent windproducing areas in North Dakota and South Dakota.

A map of the wind electric potential in the contiguous United States for class 4 and above with a 30-m hub height is shown in Figure 3 . The shading represents the average power output, in megawatts, for each grid cell of $1 / 4^{\circ}$ latitude and $1 / 3^{\circ}$ longitude. Most of the large power-producing lands are located in three major topographical areas. These are the western Great Plains from the Texas and Oklahoma Panhandles north to the Canadian border, the central Great Plains of northwestern lowa and western Minnesota, and the high plains of the Rocky 
TABLE 1. CLASSES OF WIND POWER DENSITY

\begin{tabular}{|c|c|c|c|c|c|c|}
\hline \multirow[b]{2}{*}{$\begin{array}{l}\text { Wind Power } \\
\text { Class }\end{array}$} & \multicolumn{2}{|c|}{$10 \mathrm{~m}(33 \mathrm{ft})^{(m)}$} & \multicolumn{2}{|c|}{$30 \mathrm{~m}(98 \mathrm{ft})^{(0)}$} & \multicolumn{2}{|c|}{$50 m(164 f t)^{(0)}$} \\
\hline & $\begin{array}{l}\text { Wind Power } \\
\text { Density,W/m² }\end{array}$ & $\begin{array}{c}\text { Speed(b) } \\
\mathrm{m} / \mathrm{s}(\mathrm{mph})\end{array}$ & $\begin{array}{l}\text { Wind Power } \\
\text { Density, } W / m^{2}\end{array}$ & $\begin{array}{l}\text { Speed(b) } \\
\mathrm{m} / \mathrm{s}(\mathrm{mph})\end{array}$ & $\begin{array}{l}\text { Wind Power } \\
\text { Density, W/m² }\end{array}$ & $\begin{array}{l}\text { Speed(b) } \\
\mathrm{m} / \mathrm{s} \text { (mph) }\end{array}$ \\
\hline & 0 & 0 & 0 & 0 & 0 & 0 \\
\hline 7 & 100 & $4.4 \quad(9.8)$ & 160 & $5.1(11.4)$ & 200 & $5.6(12.5)$ \\
\hline 2 & 150 & $5.1(11.5)$ & 240 & $5.9(13.2)$ & 300 & $6.4(14.3)$ \\
\hline & 200 & $5.6(12.5)$ & 320 & $6.5(14.6)$ & 400 & $7.0(15.7)$ \\
\hline 4 & 250 & $6.0(13.4)$ & 400 & $7.0(15.7)$ & 500 & $7.5(16.8)$ \\
\hline 5 & 300 & $6.4(14.3)$ & 480 & $7.4(16.6)$ & 600 & $8.0(17.9)$ \\
\hline 0 & 400 & $7.0(15.7)$ & 640 & $8.2(18.3)$ & 800 & $8.8(19.7)$ \\
\hline$\gamma$ & 1000 & $9.4(21.1)$ & 1600 & $11.0(24.7)$ & 2000 & $11.9(26.6)$ \\
\hline
\end{tabular}

WVertical extrapolation of wind power densily and wind speed are based on the 1/7 power law.

Mean wind speed is estimated assuming a Rayleigh distribution of wind speeds and standard sea-level air density. The aclual mean wind speed may differ from these estimated values by as much as $20 \%$, depending on the actual wind speed distribution and elevation above sea level.

TABLE 2. WIND ENERGY POTENTIAL PER SQUARE KILOMETER OF LAND AREA (BY WIND POWER CLASS)

Assumptions: $50-\mathrm{m}$ hub height, $10 \mathrm{D} \times 5 \mathrm{D}$ spacing, $25 \%$ efficiency, and $25 \%$ power losses

\begin{tabular}{|c|c|c|c|c|}
\hline $\begin{array}{l}\text { Power } \\
\text { Class }\end{array}$ & $\begin{array}{c}\text { Wind Power } \\
\text { Density, } \\
W / m^{2}\end{array}$ & $\begin{array}{c}\text { Average Power } \\
\text { Intercepted, } \\
\text { MW/km }\end{array}$ & $\begin{array}{l}\text { Average Power } \\
\text { Output, } \\
\text { MW/km² } \\
\end{array}$ & $\begin{array}{c}\text { Annual Energy } \\
\text { Production } \\
\text { million } \mathrm{kWh} / \mathrm{km}^{2} \\
\end{array}$ \\
\hline 3 & 350 & 5.50 & 1.03 & 9.02 \\
\hline 4 & 450 & 7.07 & 1.33 & 11.65 \\
\hline 5 & 550 & 8.64 & 1.62 & 14.19 \\
\hline 6 & 700 & 11.00 & 2.06 & 18.04 \\
\hline 7 & 900 & 14.14 & 2.65 & 23.21 \\
\hline
\end{tabular}

Mountain states of Colorado, Wyoming, and Montana. The highest power-producing grid cells (between 601 and $800 \mathrm{MW}$ ) are in the state of Wyoming because of its relatively large areas with class 6 wind resource (Table 1). Specific wind corridors in Washingtor, Oregon, and California also have significant electric potential.

Table 3 lists the top 12 states and the national totals of wind electric potential and the windy land area for power class 4 and above (assuming 30-m hub heights) and the change in percentage from the values estimated in 1991. North Dakota has the greatest wind electric potential, approximately $20 \%$ of the total ontential megawatts in the United States, with South Dakota ranking second. These two states account for over one-third of the wind energy potential in the contiguous United States. Four states, Wyoming, New Mexico, Minriesota, and Montana, had increases of more than $3 \%$ of wind electric potential over the 1991 estimates. Texas, Colorado, and the Dakotas had lower electric potential and windy land area estimates, by more than 2\%, than those made in 1991. 


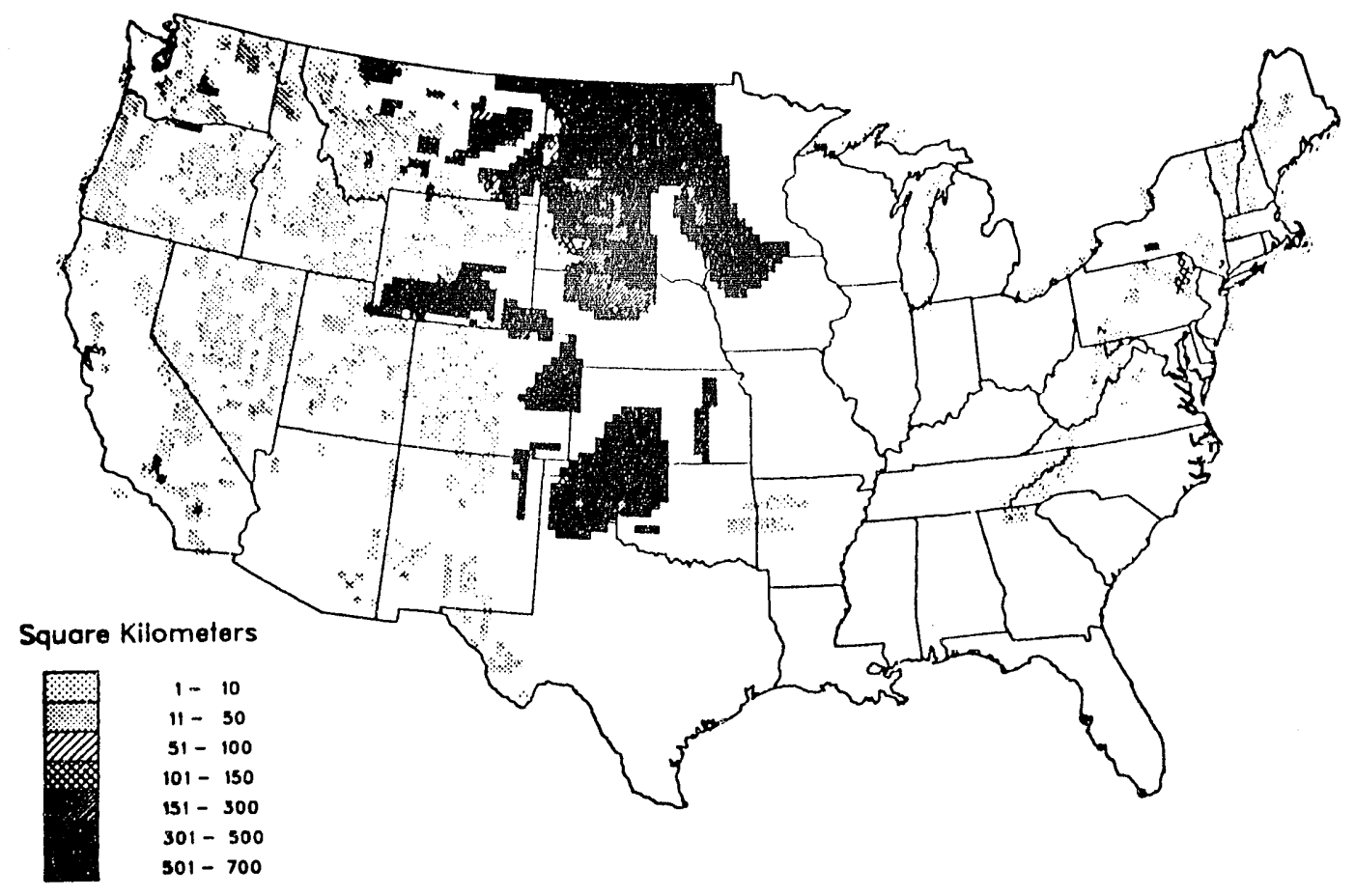

FIG. 2a. AVAILABLE WINDY LAND OF EACH GRID CELL (IN SQUARE KILOMETERS) FOR CLASS 4 AND ABOVE

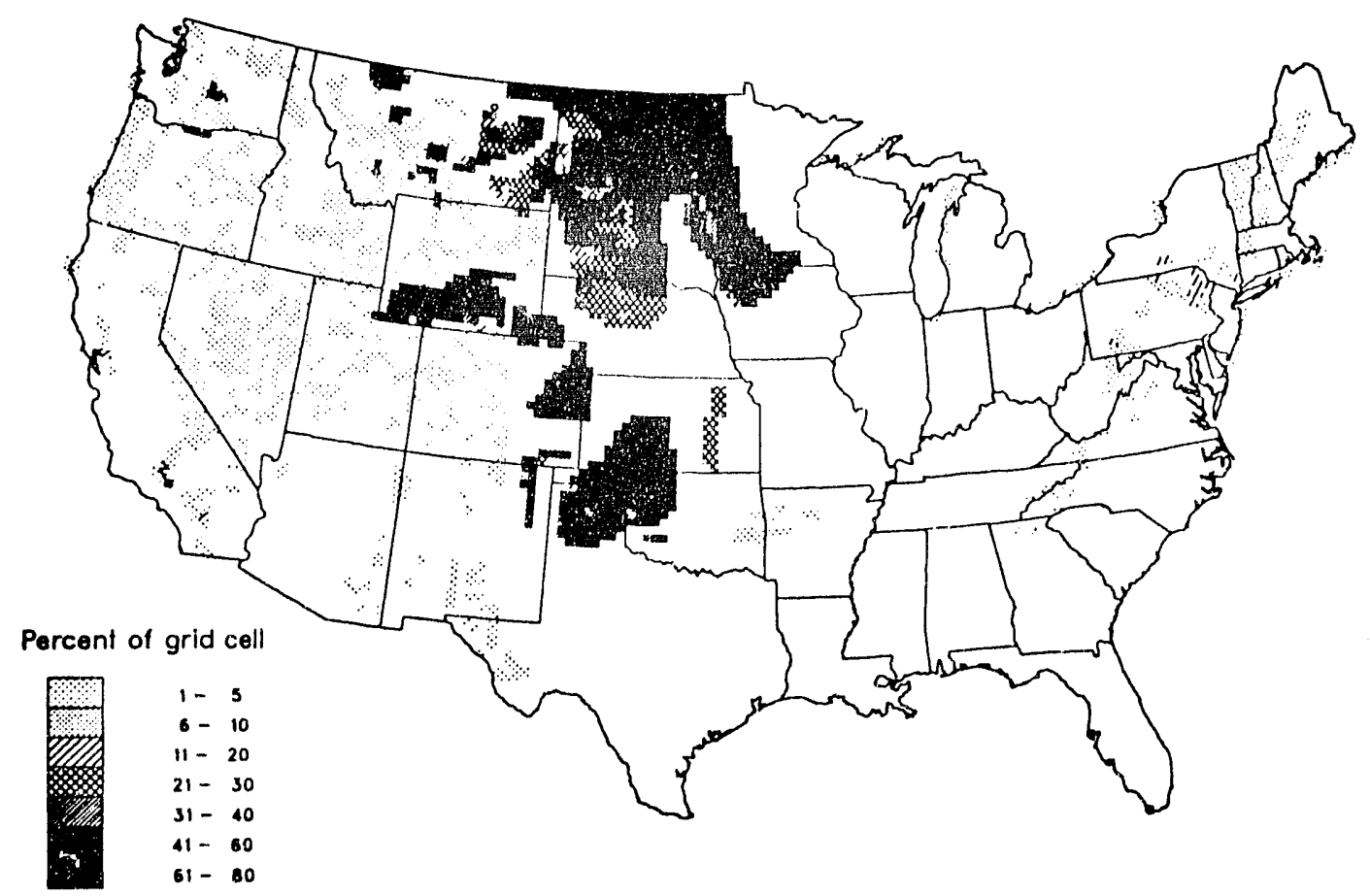

FIG. 2b. AVAILABLE WINDY LAND AS A PERCENT OF EACH GRID CELL FOR CLASS 4 AND ABOVE 


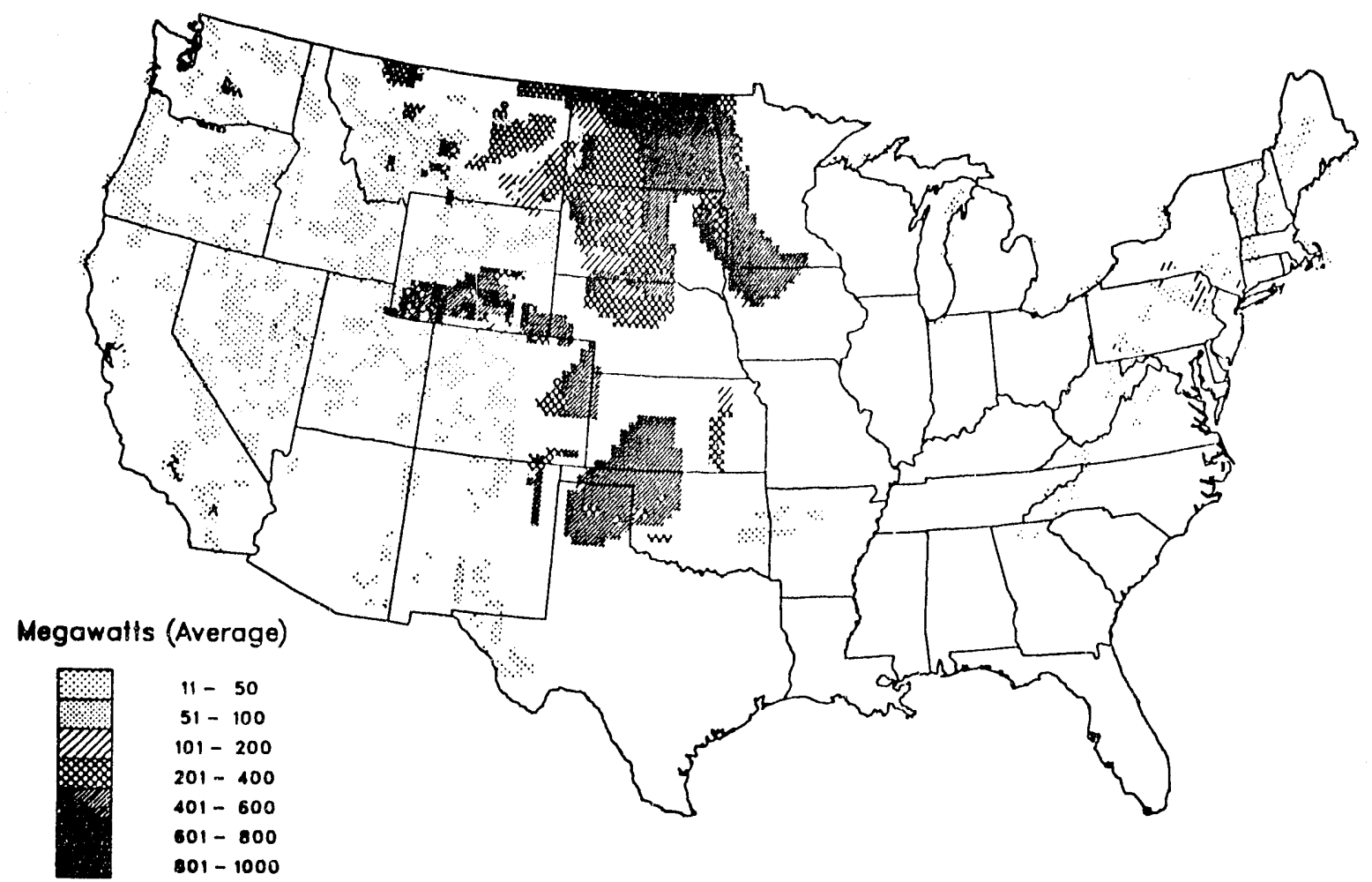

FIG. 3. WIND ELECTRIC POTENTIAL OF EACH GRID CELL (IN MEGAWATTS) FOR CLASS 4 AND ABOVE (30-M HUB HEIGHT)

TABLE 3. ESTIMATES OF CLASS 4 WINDY LAND AREA AND WIND ENERGY POTENTIAL (The top 12 states and total for 48 contiguous states) Wind resource class 4 and above, for a 30-m hub height.

\begin{tabular}{|c|c|c|c|c|c|}
\hline State & $\therefore$ & $\begin{array}{c}\text { Average Power, } \\
\text { MW }\end{array}$ & $\begin{array}{l}\text { Percent Change } \\
\text { from } 1991 \\
\end{array}$ & $\begin{array}{c}\text { Windy Land, } \\
\mathrm{km}^{2}\end{array}$ & $\begin{array}{c}\text { Percent Change } \\
\text { from } 1991 \\
\end{array}$ \\
\hline North Dakota & & 108,000 & -2.1 & 98,000 & -2.0 \\
\hline South Dakota & & 70,900 & -2.5 & 66,500 & -2.3 \\
\hline Wyoming & & 49,800 & +6.4 & 39,600 & +5.9 \\
\hline Montana & & 48,400 & +3.4 & 42,800 & +3.1 \\
\hline Minnesota & . & 44,800 & +4.7 & 42,100 & +4.7 \\
\hline Kansas & & 35,700 & +0.8 & 33,600 & +0.9 \\
\hline Texas & & 28,900 & -5.9 & 27,100 & -5.9 \\
\hline Oklahoma & & 27,200 & 0.0 & 25,500 & 0.0 \\
\hline Colorado & & 26,400 & -2.9 & 24,300 & -4.0 \\
\hline Nebraska & & 22,200 & -0.9 & 20,900 & -0.9 \\
\hline lowa & & 15,800 & -1.2 & 14,900 & -0.7 \\
\hline New Mexico & & 5,200 & +4.8 & 4,600 & +2.2 \\
\hline National & & 512,300 & +1.0 & 464,200 & +0.7 \\
\hline \multicolumn{3}{|c|}{$\begin{array}{l}\text { Percent of U.S. Area } \\
\text { (48 Contiguous) }\end{array}$} & & $\begin{array}{l}1992-6.0 \% \\
1991-6.0 \%\end{array}$ & \\
\hline
\end{tabular}


The decrease in windy lands in Texas and Colorado, the states with the largest decrease in available windy lands, seems related to the presence of national grasslands in the windy areas of northern Texas and eastern Colorado.

Figure 4 shows the wind energy potential calculated for an advanced wind turbine technology scenario that would allow areas with class 3 or higher (assuming 50-m hub heights) to be developed. The Great Plains from central Texas north to the Canadian border and from lowa west to the Rocky Mountains has significant wind electric potential. In addition, other areas of the contiguous states have grid cells with energy potential of at least $200 \mathrm{MW}$. These areas include specific wind corridors in the western states, the shores of Lakes Michigan and Ontario, the Gulf of Mexico coastline in Texas, west-central Illinois, southwestern and east-central ldaho, central Massachusetts, and northern Maine. However, some windy land in these regions may not be open to wind energy development because of private property considerations or other institutional concerns.

Table 4 presents the top 12 states and the national totals of wind electric potential and windy lands for class 3 and above (assuming 50-m hut heights) and the change of the values, in percent, from the 1991 report. North Dakota and Texas are within $300 \mathrm{MW}$ in average power potential. North Dakota's electric potential and windy land area are $2 \%$ lower than estimated in 1991, while land and electric potential in Texas is approximately $2 \%$ higher than the 1991 estimate. Colorado had the largest decrease of average power potential (4\%) and windy lands (5\%), while Wyoming had the largest increase in average power potential and windy land area from the 1991 estimate $(2.6 \%$ and $7.1 \%$, respectively). Wyoming's large increase in electric potential seems to be related to the low number of designated environmental areas in the windy complex terrain of southwestern Wyoming.

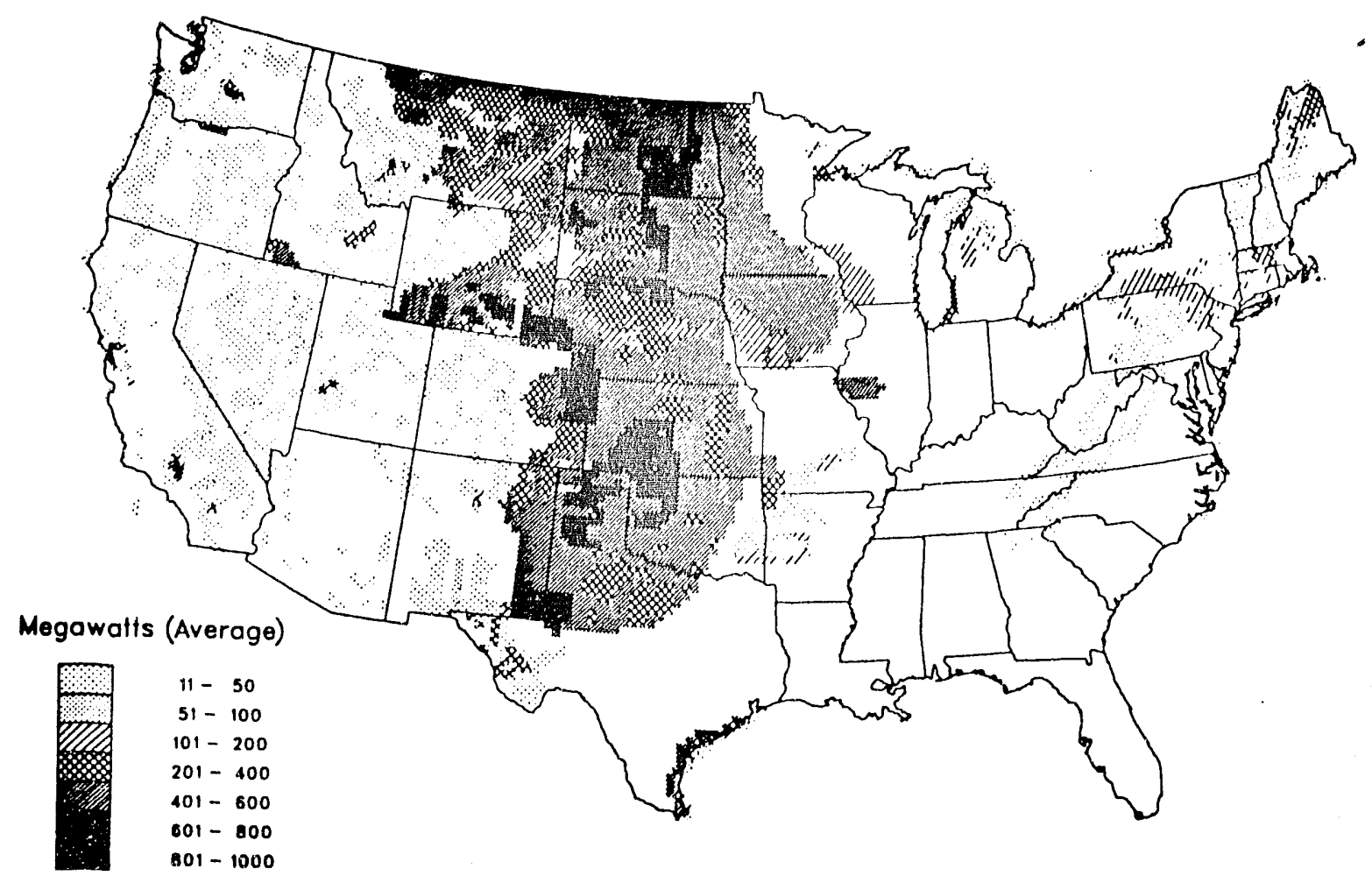

FIG. 4. WIND ELECTRIC POTENTIAL OF EACH GRID CELL (IN MEGAWATTS) FOR CLASS 3 AND ABOVE (50-M HUB HEIGHT) 
TABLE 4. ESTIMATES OF CLASS 3 WINDY LAND AREA AND WIND ENERGY POTENTIAL (The top 12 states and total for 48 contiguous states) Wind resource class 3 and above, for a 50-m hub height.

\begin{tabular}{|c|c|c|c|c|}
\hline State & $\begin{array}{c}\text { Average Power, } \\
\text { MW }\end{array}$ & $\begin{array}{l}\text { Percent Change } \\
\text { from } 1991\end{array}$ & $\begin{array}{l}\text { Windy Land, } \\
\mathrm{km}^{2}\end{array}$ & $\begin{array}{l}\text { Percent Change } \\
\text { from } 1991\end{array}$ \\
\hline North Dakota & 135,200 & -2.0 & 98,300 & -2.4 \\
\hline Texas & 134,900 & +2.0 & 125,900 & +1.8 \\
\hline Kansas & 121,900 & 0.0 & 108,600 & 0.0 \\
\hline Montana & 118,300 & +2.0 & 100,100 & +2.9 \\
\hline South Dakota & 114,500 & -2.3 & 91,800 & -2.0 \\
\hline Nebraska & 99,200 & +0.1 & 90,300 & +0.2 \\
\hline Wyoming & 87,400 & +2.6 & 67,900 & +7.1 \\
\hline Oklahoma & 83,700 & +1.2 & 73,900 & +1.4 \\
\hline Minnesota & 76,300 & +1.7 & 61,900 & +1.3 \\
\hline lowa & 62,900 & 0.0 & 56,900 & +0.4 \\
\hline Colorado & 52,700 & -4.0 & 43,400 & -5.0 \\
\hline New Mexico & 49,800 & +0.2 & 46,500 & -0.2 \\
\hline National & $1,241,200$ & +0.9 & $1,059,100$ & +1.8 \\
\hline \multicolumn{2}{|c|}{$\begin{array}{l}\text { Percent of U.S. Area } \\
\text { ( } 48 \text { Contiguous) }\end{array}$} & \multicolumn{3}{|c|}{$\begin{array}{l}1992-13.8 \% \\
1991-13.5 \%\end{array}$} \\
\hline
\end{tabular}

\section{DIFFERENCES IN NATIONAL ESTIMATES BETWEEN 1991 AND 1992}

The estimates of available windy land and wind electric potential output for the contiguous United States were slightly higher in 1992, using the "actual" distribution of environmental exclusion areas, than the 1991 estimates made using the approximate distribution of environmental exclusion areas. The amount of windy lands for power class 4 and above is approximately 464,200 square kilometers in the 1992 estimate compared with 460,600 square kilometers in 19.91 , or about $0.7 \%$ greater. In both estimates, the amount of windy land as a percentage of the total land area in the contiguous United States is 6\%. The 1992 estimate of wind electric potential increased by $1 \%$, to $512,300 \mathrm{MW}$. Available windy lands for power class 3 and above are estimated to make up $13.8 \%$ of the total land area of the contiguous United States in the 1992 estimate, compared to $13.5 \%$ in 1991. There are approximately 19,100 more square kilometers (1.8\%) of windy land using the "actual" environmental exclusions than in the 1991 estimate based on land surface features. The 1992 estimate of average power potential is $1,241,200 \mathrm{MW}$, approximately $10,900 \mathrm{MW}(0.9 \%)$ more than the estimate made in 1991.

\section{CONCLUSION}

Revised estimates of available windy land area and electric power potential were made in 1992 using the "actual" distribution of environmentally sensitive areas and a "moderate" land-use scenario. Gridded maps of windy lands and potential power for the contiguous United States were produced. Though the changes in a few states were relatively large, overall the revised values of land area and power were just slightly higher ( $1 \%$ to $2 \%$ ) in the 1992 estimate then they were in the 1991 report.

Important factors not addressed in this study that influence windy land availability and total electric potential include production/demand match (seasonal and daily), transmission and access constraints, public acceptance, and other technological and institutional constraints. 
This study of the quantitative estimate of the overall resource does not diminish the need for, but rather should enhance the development of, resource verification and siting studies using improved terrain resolution in areas estimated to have excellent wind resource potential.

\section{ACKNOWLEGMENTS}

We wish to thailk Alan Peoples for his work on the new gridded data base of environmental exclusion areas. This work was supported by the U.S. Department of Energy under Contract DE-AC06-76RLO 1830 at the Pacific Northwest Laboratory, which is operated by Battelle Memorial Institute.

\section{REFERENCES}

1. Elliott, D. L., C. G. Holladay, W. R. Barchet, H. P. Foote, and W. F. Sandusky. 1987. Wind Energy Resource Atlas of the United States. DOE/CH 10093-4, Solar Energy Research Institute, Golden, Colorado.

2. Elliott, D. L., L. L. Wendell, and G. L. Gower. 1991. An Assessment of the Available Windy Land Area and Wind Energy Potential in the Contiguous United States. PNL-7789, Pacific Northwest Laboratory, Richland, Washington. 

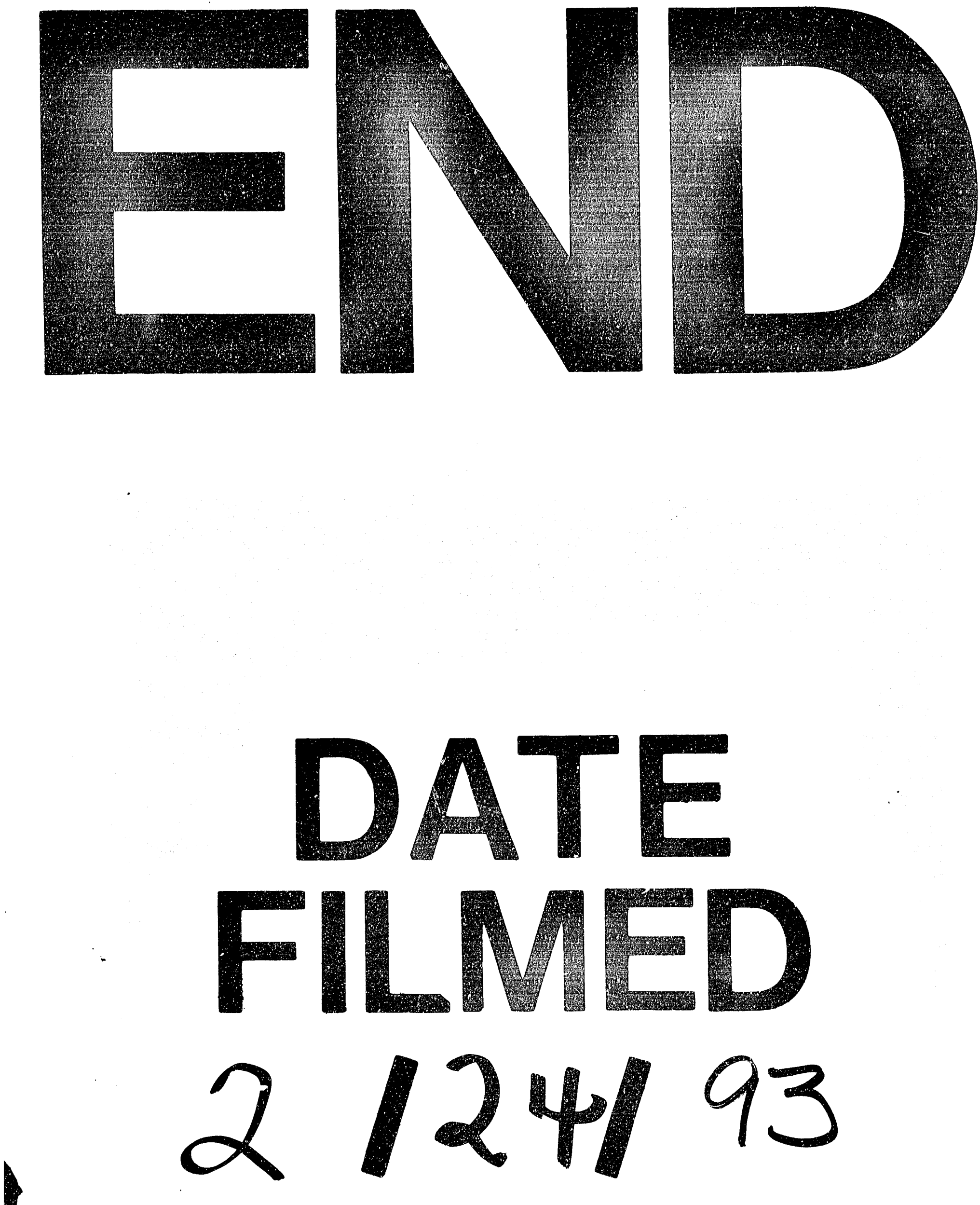
